\title{
INNOWACYJNY MODEL PROCESU DIAGNOSTYCZNO-LECZNICZEGO
}

\author{
Katarzyna Łyp ${ }^{1}$ \\ Uniwersytet Opolski \\ Wydział Lekarski, Zakład Medycyny Rodzinnej i Zdrowia Publicznego
}

\begin{abstract}
Streszczenie: Wewnętrzne rozwiązania w jednostkach medycznych, kształtujące porządek czynności wchodzących w skład procesu diagnostyczno-leczniczego przewidzianego dla polskiego pacjenta, zagrażają bezpiecznemu i skutecznemu uzyskaniu korzyści terapeutycznych, stwarzając jedynie pozory starań pracowników. Celem głównym artykułu jest przedstawienie autorskiego, innowacyjnego modelu procesu diagnostyczno-terapeutycznego, który pozwolił na skuteczne zaspokojenie społecznego zapotrzebowania na usługi zdrowotne w Polsce. Podmiot badań empirycznych stanowili pacjenci oddziałów Uniwersyteckiego Szpitala Klinicznego w Opolu. Przedmiotem badań była gotowość pacjentów do współpłacenia za poszczególne etapy procesu diagnostyczno-terapeutycznego oraz deklarowana wysokość współpłacenia. Przeprowadzono badanie ankietowe uzupełnione wywiadem.
\end{abstract}

Słowa kluczowe: ochrona zdrowia, realizacja procesu diagnostyczno-leczniczego, zarządzanie w ochronie zdrowia

DOI: $10.17512 /$ znpcz.2021.3.05

\section{Wprowadzenie}

Spójna analiza procesów diagnostyczno-leczniczych proponowanych potencjalnemu pacjentowi w Polsce wymaga sprecyzowania fundamentalnych definicji kształtujących rodzimą politykę zdrowotną. Ustalono zatem, że polityka zdrowotna (European Observatory... 2021) to formalna procedura stosowana w sytuacjach, w których ustala się priorytety i parametry działania, jakie podejmowane są w odpowiedzi na społeczne potrzeby zdrowotne, biorąc pod uwagę dostępne zasoby. Rozsądne wydaje się zatem podjęcie działań mających na celu rzetelne zdefiniowanie potrzeb zdrowotnych obywateli danego kraju, z uwzględnieniem zarówno zasobów, jak i możliwości systemu, aby na tej podstawie sprecyzować priorytety, a w dalszym etapie parametry naprawcze skierowane do - jak się wydaje - niedomagającego systemu ochrony zdrowia. Systemu, który - w myśl definicji systemu - powinien, jako zespół wzajemnie powiązanych elementów, realizować założone cele (Bukowska-Piestrzyńska 2007, s. 51). Tymczasem wewnętrzne rozwiązania poszczególnych podmiotów leczniczych, kształtujące przebieg udzielenia świadczenia medycznego, zagrażają skuteczności zachowania, ratowania lub przywracania zdrowia pacjenta w Polsce.

\footnotetext{
${ }^{1}$ Katarzyna Łyp, dr inż., katarzyna.lyp@ @uni.opole.pl, ORCID: 0000-0003-0520-454X
} 
Wśród zadań wspomnianej powyżej polityki zdrowotnej kraju jednym z najważniejszych jest odpowiednia organizacja procesu leczenia (CEESTAHC 2017). Natomiast celem polityki zdrowotnej jest realizacja - poprzez zorganizowany i skoordynowany zestaw działań - świadczeń usług profilaktyczno-leczniczych, usług diagnostyczno-leczniczych i rehabilitacyjnych w ramach ogółu podmiotów i instytucji powołanych do organizowania finansowania i udzielania świadczeń opieki zdrowotnej. Tutaj z kolei można domniemać, że wszelkiego rodzaju działania skierowane do potencjalnego pacjenta mają charakter wysoce zorganizowany i skoordynowany. Ponieważ powinnością organizacji ochrony zdrowia jest dostarczenie pacjentowi więcej, aniżeli oczekuje (Jopkiewicz 2019, s. 79). Tak zarysowane tło polityki zdrowotnej naszego kraju, które od wielu lat nie pozwala na realizację swoich podstawowych zadań i celów, wymaga zmian przyczyniających się do zgodnej z zapotrzebowaniem społecznym realizacji świadczeń zdrowotnych.

Zatem celem niniejszego artykułu jest zaprezentowanie autorskiego, innowacyjnego modelu procesu diagnostyczno-leczniczego, który pozwoliłby na efektywne zaspokojenie zapotrzebowania społecznego na usługi zdrowotne w Polsce.

\section{Przegląd literatury}

Jednym z najlepiej zorganizowanych systemów ochrony zdrowia w Europie jest system duński, charakteryzujący się wysokim stopniem powszechności dostępu obywateli do świadczeń medycznych. Wydatki na opiekę zdrowotną w Danii wynoszą $11 \%$ PKB. Finansowanie w $85 \%$ ma źródło w środkach publicznych, pochodzących z podatku bezpośredniego w wysokości $8 \%$ od dochodu. Pozostałe $15 \%$ jest częściowo subsydiowane przez państwo, ale wymaga również współpłacenia bezpośredniego pacjentów (https://pl.europa.jobs/...). Obecnie polityczno-administracyjna odpowiedzialność za system ochrony zdrowia jest w Danii podzielona pomiędzy rząd centralny, regiony oraz gminy. Do obowiązków rządu należy ustalanie regulacji oraz ram prawnych dotyczących ochrony zdrowia (Schmidt i in. 2019, s. 563-591). Ponadto rząd odpowiada za nadzór nad jakością świadczonych usług oraz analizę wydajności i efektywności całego systemu, a także opiekę nad osobami starszymi. Do zakresu odpowiedzialności pięciu duńskich regionów należy finansowanie oraz zarządzanie specjalistyczną opieką zdrowotną, szpitalami, centrami usług prenatalnych oraz zdrowia psychicznego. Regiony odpowiadają również za wypłaty wynagrodzeń dla lekarzy pierwszego kontaktu, specjalistów, psychoterapeutów, dentystów czy farmaceutów. Odpowiedzialność 98 duńskich gmin dotyczy zarządzania domami opieki nad osobami starszymi, centrami rehabilitacyjnymi, opieką medyczną w szkołach (w tym opieką dentystyczną) (Szymaszek 2018, s. 4-9). Celem strategii rozwoju duńskiego systemu ochrony zdrowia jest zmniejszenie liczby hospitalizacji poprzez inwestycje w badania profilaktyczne, telemedycynę oraz opiekę domową nad pacjentami przewlekle chorymi (Healthcare in Denmark... 2017; https:/www.politykazdrowotna.com/...; https:/www.zus.pl/...).

Kolejnym, równie dobrze zorganizowanym systemem ochrony zdrowia jest system norweski, oparty na częściowo zmodyfikowanym modelu Beveridge'a. System publicznej opieki zdrowotnej podlega Ministerstwu Zdrowia i Spraw Społecznych. 
Wykonywanie usług lekarskich zostało podzielone na dwa szczeble: lokalne (gminne) i regionalne (wojewódzkie). Na poziomie lokalnym gminy odpowiadają za zapewnienie wszystkim członkom systemu ubezpieczeń społecznych podstawowej opieki zdrowotnej. Gminy zapewniają zatem takie świadczenia zdrowotne jak: kontakt z lekarzami rodzinnymi, pomoc lekarska w nagłych wypadkach, opieka fizjoterapeutyczna, przychodnie matki i dziecka, pielęgniarki szkolne, opieka nad chorym w domu, opieka położnicza, domy opieki i ośrodki opieki całodobowej. Natomiast na poziomie regionalnym (województwa) zajmują się specjalistyczną opieką lekarską, szpitalami oraz opieką stomatologiczną. Obok placówek publicznych funkcjonuje kilka autoryzowanych szpitali prywatnych i prywatne praktyki lekarskie (Healthcare in Denmark... 2017; https:/www.politykazdrowotna.com/...; https:/www.zus.pl/...). Źródła publiczne pokrywają zdecydowaną większość wydatków na zdrowie - około 85,2\%. $14,8 \%$ pozostałych wydatków na usługi zdrowotne mieszkańcy Norwegii pokrywają z własnej kieszeni. Udział ten przekracza średnią UE wynoszącą 79,0\% i średnią OECD (Organizacja Współpracy Gospodarczej i Rozwoju) wynoszącą 72,9\% (Wismar, Busse, Schwartz 1999).

\section{Metodyka badania}

Założeniem autorki niniejszego artykułu jest zastosowanie triangulacji metodologicznej, rozumianej jako zwielokrotnienie metod i technik badawczych oraz danych, pochodzących z wielu źródeł. Pozwala to na wzajemną weryfikację, relatywizację, dopełnienia i dookreślenia (Korporowicz 1997, s. 278; Jasiński, Kowalski 2007, s. 101). Metody badawcze zastosowane w artykule obejmują wszechstronną analizę danych uzyskanych w wyniku badań, których podmiotem byli pacjenci oddziałów Uniwersyteckiego Szpitala Klinicznego w Opolu. Przedmiot badań stanowiły dane uzyskane za pomocą kwestionariusza ankiety, jako narzędzia badań ilościowych, oraz wywiadu ustrukturyzowanego, jako narzędzia badań jakościowych. Badania przeprowadzono w czwartym kwartale 2010 roku oraz pierwszym kwartale 2021 roku. Początkowe pytania kwestionariusza ankiety pozwoliły na demograficzną analizę grupy poddanej badaniu. Pozostałe zmienne losowe, uzyskane w wyniku powyższych badań ilościowych, jak i jakościowych, posłużyły do badań statystycznych, przy użyciu zarówno miar klasycznych, jak i miar pozycyjnych. W pracy postawiono hipotezy statystyczne, które poddano weryfikacji za pomocą jednoczynnikowej analizy wariancji ANOVA. Każdemu etapowi badań statystycznych towarzyszą kolejne interpretacje uzyskanych wyników. Na podstawie uzyskanych wyników i poszczególnych interpretacji wygenerowano wnioskowanie statystyczne.

Badaniu poddano:

- wiek pacjentów deklarujących (lub nie) gotowość do współpłacenia za poszczególne etapy procesu diagnostyczno-leczniczego proponowanego (w niniejszym artykule) innowacyjnego modelu procesu diagnostyczno-leczniczego;

- gotowość pacjentów do współpłacenia za poszczególne etapy procesu diagnostyczno-leczniczego oraz deklarowaną wysokość współpłacenia proponowanego (w niniejszym artykule) innowacyjnego modelu procesu diagnostyczno-leczniczego; 
- zmienne losowe uzyskane w wyniku dokonania symulacji czasu trwania poszczególnych etapów procesu diagnostyczno-leczniczego, zaproponowanego w niniejszym artykule.

\section{Analiza wyników badań własnych}

Poniższy wykres (Rysunek 1) przedstawia podział pacjentów ze względu na wolę i/lub brak woli współpłacenia za usługi medyczne w innowacyjnym procesie diagnostyczno-leczniczym proponowanym w niniejszym artykule.

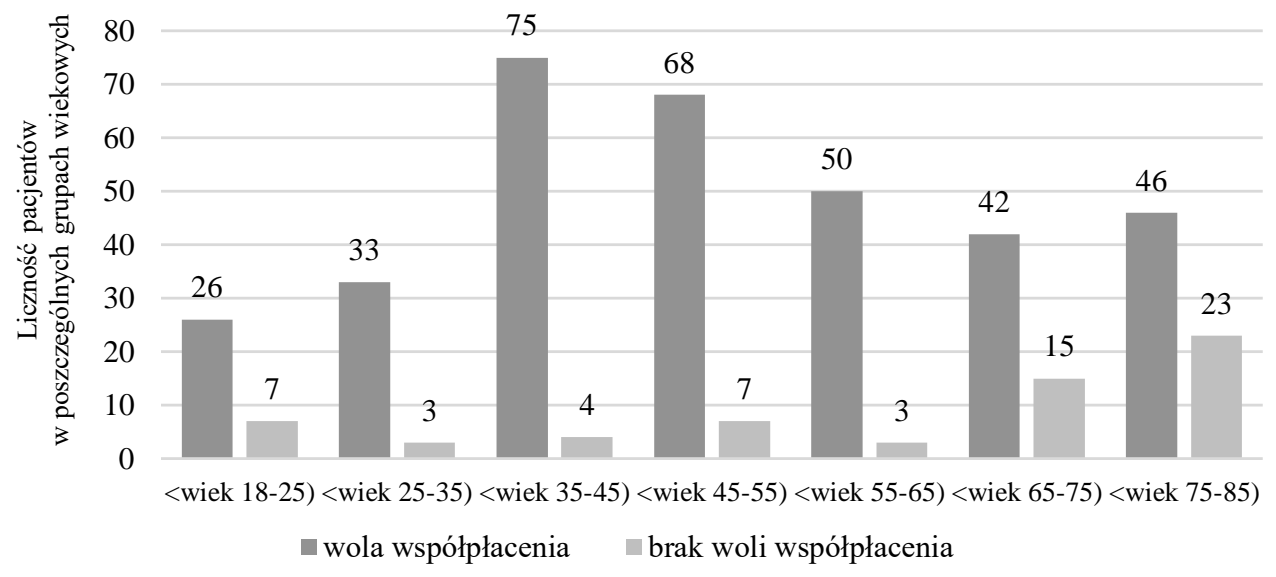

\section{Rysunek 1. Podział pacjentów na grupy: z wolą i/lub brakiem woli współpłacenia za usługi medyczne w nowym modelu procesu diagnostyczno- -leczniczego}

Źródło: Opracowanie własne

Jak wskazują dane zawarte na Rysunku 1 , w przedziale wiekowym $\langle 18-25)$ lat około $63 \%$ badanych wyraża wolę współpłacenia za usługi medyczne w nowym proponowanym modelu procesu diagnostyczno-leczniczego. W przedziale wiekowym 〈25-35) lat aż 91\% badanych wyraża wolę współpłacenia za wspomniane powyżej usługi medyczne. W kolejnym przedziale wiekowym, $\langle 35-45)$ lat, około $95 \%$ badanych osób wyraża taką wolę. W przedziale wiekowym (45-55) lat również 90\% badanych wyraża wolę współpłacenia. Równie dużą grupę osób gotowych współpłacić za usługi medyczne stanowią badani w grupie wiekowej $\langle 55-65$ ) lat - aż 94\%. Natomiast w przedziale wiekowym $\langle 65-75)$ lat wola współpłacenia za usługi medyczne $\mathrm{w}$ proponowanym modelu procesu diagnostyczno-leczniczego maleje do $64 \%$, by w przedziale osób najstarszych, $\langle 75-85$ ) lat, zmaleć do około 50\%.

Ciekawe wydają się przyczyny wskazywane przez poszczególne grupy wiekowe, dotyczące braku wyrażenia woli współpłacenia. W niniejszym artykule przedstawiono maksymalnie dwie przyczyny z największą licznością wśród uzyskanych odpowiedzi. 
$\mathrm{W}$ przedziale wiekowym $\langle 18-25)$ lat oraz $\langle 25-35)$ lat dominowały odpowiedzi: nie wiem; nie mam zdania. Następnie: w przedziale wiekowym $\langle 35-45)$ oraz $\langle 45-55)$ lat dominują odpowiedzi: płace na ZUS i należa mi się ustugi medyczne $w$ ramach NFZ. W przedziale wiekowym $\langle 55-65)$ lat dominują odpowiedzi: brak środków (oszczędności); płacę/płaciłam/płaciłem na ZUS i należa mi się ustugi medyczne $w$ ramach NFZ. W przedziale wiekowym $\langle 65-75)$ lat dominują odpowiedzi: brak środków (oszczędności); brak wiary w możliwość organizacji tego rodzaju przedsięwzięcia. W przedziale (75-85) lat dominują odpowiedzi: jedyny powód to brak środków (oszczędności).

Tabela 1. Korelacja pomiędzy wiekiem pacjenta (w przedziałach wiekowych) a deklarowanym poziomem wspólpłacenia

\begin{tabular}{|c|c|c|c|c|c|c|c|c|}
\hline $\mathbf{X} \backslash \mathbf{Y}$ & $\langle\mathbf{1 0 - 2 0})$ & $\langle\mathbf{2 0 - 3 0})$ & $\langle\mathbf{3 0 - 4 0 )}$ & $\langle\mathbf{4 0 - 5 0 )}$ & $\langle\mathbf{5 0 - 6 0}$ & $\langle\mathbf{6 0 - 7 0}$ & $\langle\mathbf{7 0 - 8 0})$ & $\begin{array}{c}\text { brzegowy } \\
\mathbf{X}\end{array}$ \\
\hline$\langle\mathbf{1 8 - 2 5})$ & 0 & 3 & 4 & 4 & 5 & 5 & 5 & $\mathbf{2 6}$ \\
\hline$\langle\mathbf{2 5 - 3 5})$ & 0 & 1 & 2 & 6 & 8 & 8 & 8 & $\mathbf{3 3}$ \\
\hline$\langle\mathbf{3 5 - 4 5})$ & 0 & 6 & 9 & 10 & 12 & 16 & 22 & $\mathbf{7 5}$ \\
\hline$\langle\mathbf{4 5 - 5 5 )}$ & 2 & 0 & 6 & 12 & 14 & 16 & 18 & $\mathbf{6 8}$ \\
\hline$\langle\mathbf{5 5 - 6 5})$ & 3 & 12 & 16 & 6 & 5 & 3 & 5 & $\mathbf{5 0}$ \\
\hline$\langle\mathbf{6 5 - 7 5})$ & 22 & 16 & 2 & 2 & 0 & 0 & 0 & $\mathbf{4 2}$ \\
\hline$\langle\mathbf{7 5 - 8 5}\rangle$ & 26 & 14 & 4 & 2 & 0 & 0 & 0 & $\mathbf{4 6}$ \\
\hline $\begin{array}{c}\text { brzegowy } \\
\mathbf{Y}\end{array}$ & $\mathbf{5 3}$ & $\mathbf{5 2}$ & $\mathbf{4 3}$ & $\mathbf{4 2}$ & $\mathbf{4 4}$ & $\mathbf{4 8}$ & $\mathbf{5 8}$ & $\mathbf{3 4 0}$ \\
\hline
\end{tabular}

Źródło: Opracowanie własne

Dane x: wiek poszczególnych pacjentów w podziale na grupy wiekowe:

$$
\bar{x}=\frac{\sum_{i=1}^{k} \dot{x}_{i} n_{i}}{n}=\frac{\dot{x}_{1} n_{1}+\dot{x}_{2} n_{2}+\ldots+\dot{x}_{w} n_{w}}{n}=\frac{17569}{340}=51,67352941
$$

Interpretacja: średni wiek osób objętych badaniem empirycznym wynosi około 51,7 roku.

$$
\begin{gathered}
S_{(x)}^{2}=\frac{\sum_{i=1}^{k}\left(\dot{x}_{i}-\bar{x}\right) * n_{i}}{n}=\frac{104066,2618}{340}=306,07724 \\
S(x)=\sqrt{S^{2}}=\sqrt{306,07724}=17,49506
\end{gathered}
$$

Interpretacja: w myśl reguły 3 Sigma wiek około $68,3 \%$ pacjentów poddanych badaniu odchyla się przeciętnie o $\pm \sigma$ (czyli \pm około 17,5 roku od średniej).

Dane y: deklarowana kwota współpłacenia za jednorazową wizytę u lekarza $\mathrm{w}$ nowym, proponowanym $\mathrm{w}$ niniejszym artykule modelu procesu diagnostycznoleczniczego.

$$
\bar{y}=\frac{\sum_{i=1}^{k} \dot{y}_{i} n_{i}}{n}=\frac{\dot{y}_{1} n_{1}+\dot{y}_{2} n_{2}+\ldots+\dot{y}_{w} n_{w}}{n}=\frac{9730}{340}=27,617647
$$

Interpretacja: średnia deklarowana kwota współpłacenia za jednorazową wizytę u lekarza w nowym, proponowanym w niniejszym artykule modelu procesu diagnostyczno-leczniczego wynosi około 27,6 zł. 


$$
\begin{aligned}
& S_{(y)}^{2}=\frac{\sum_{i=1}^{k}\left(\dot{y}_{i}-\bar{x}\right) * n_{i}}{n}=\frac{27,61747}{340}=109,2509 \\
& S_{(y)}=\sqrt{s_{y}^{2}}=\sqrt{109,2509}=10,4523139
\end{aligned}
$$

Interpretacja: $\mathrm{w}$ myśl reguły 3 Sigma deklarowana przez pacjentów poddanych badaniu kwota współpłacenia za jednorazową wizytę u lekarza w nowym, proponowanym w niniejszym artykule modelu procesu diagnostyczno-leczniczego odchyla się przeciętnie o $\pm \sigma$ (czyli \pm około $10,45 \mathrm{zł}$ od średniej).

Obliczenie kowariancji:

$$
\operatorname{cov}(x, y)=\frac{\sum_{i} \sum_{i}\left(\dot{x}_{i}-\bar{x}\right)\left(\dot{y}_{j}-\bar{y}\right) n_{i j}}{n}=\frac{-16328,2}{330}=-48,02398789
$$

Interpretacja: ujemna zależność kowariancji świadczy, że wraz ze wzrostem wieku pacjentów maleje deklarowana kwota chęci współpłacenia za jednorazową wizytę u lekarza $\mathrm{w}$ nowym, proponowanym $\mathrm{w}$ niniejszym artykule modelu procesu diagnostyczno-leczniczego.

Współczynnik korelacji liniowej Pearsona:

$$
r=\frac{\operatorname{cov}(x, y)}{S_{(x)} \times S_{(y)}}=\frac{-48,02398789}{17,49506 \times 10,4523139}=0,266215
$$

Interpretacja: wartość bezwzględna mówiąca o sile ww. zależności definiuje wspomnianą zależność jako słabą.

Wnioskowanie statystyczne dotyczące korelacji pomiędzy wiekiem a wysokością kwoty, którą skłonni są zapłacić respondenci badań empirycznych za jednorazową wizytę u lekarza/lekarzy, w nowym, proponowanym w niniejszym artykule modelu procesu diagnostyczno-leczniczego wskazuje na ujemną co do kierunku i słabą co do sily korelację.

Na Rysunku 2 przedstawiono liczność w poszczególnych grupach wiekowych deklarujących chęci współpłacenia danej kwoty za jednorazową wizytę u lekarza/lekarzy w nowym, proponowanym w niniejszym artykule modelu procesu diagnostyczno-leczniczego.

Korelacja pomiędzy wysokością kwoty współpłacenia a liczbą osób gotowych zapłacić daną kwotę za usługę medyczną w proponowanym procesie diagnostycznoleczniczym zaprezentowana na Rysunku 2 wskazuje rozkład uzyskanych wyników: najliczniej deklarowana kwota współpłacenia to zakres 77-80 zł - około 17\% badanych deklaruje taką wolę, a następnie kolejno: zakres 10-20 zł deklaruje około 15,6\% badanych, 20-30 zł deklaruje około 15,3\% badanych, $60-70 \mathrm{zł}$ deklaruje około $14 \%$ badanych, 50-60 zł deklaruje około 13\% badanych, 30-40 zł deklaruje około 12,6\% badanych oraz 40-50 zł deklaruje około $10 \%$ badanych.

Rozkład uzyskanych wyników prezentuje się następująco: grupa wiekowa $\langle 18-25)$ najliczniej deklaruje kwotę 30-40 zł, a następnie kolejno: grupa wiekowa (25-35) deklaruje 50-80 zl, grupa wiekowa $\langle 35-45$ ) deklaruje 70-80 zl, grupa wiekowa $\langle 45-55)$ deklaruje 70-80 zł, grupa wiekowa $\langle 55-65)$ deklaruje 30-40 zł, grupa wiekowa $\langle 65-75)$ deklaruje 10-20 zł, grupa wiekowa $\langle 75-85)$ deklaruje 10-20 zł. 
Liczność grupy osób poddanych badaniu empirycznemu pozwala wstępnie sądzić, że proponowany proces diagnostyczno-leczniczy uzyskałby aprobatę wśród społeczeństwa.

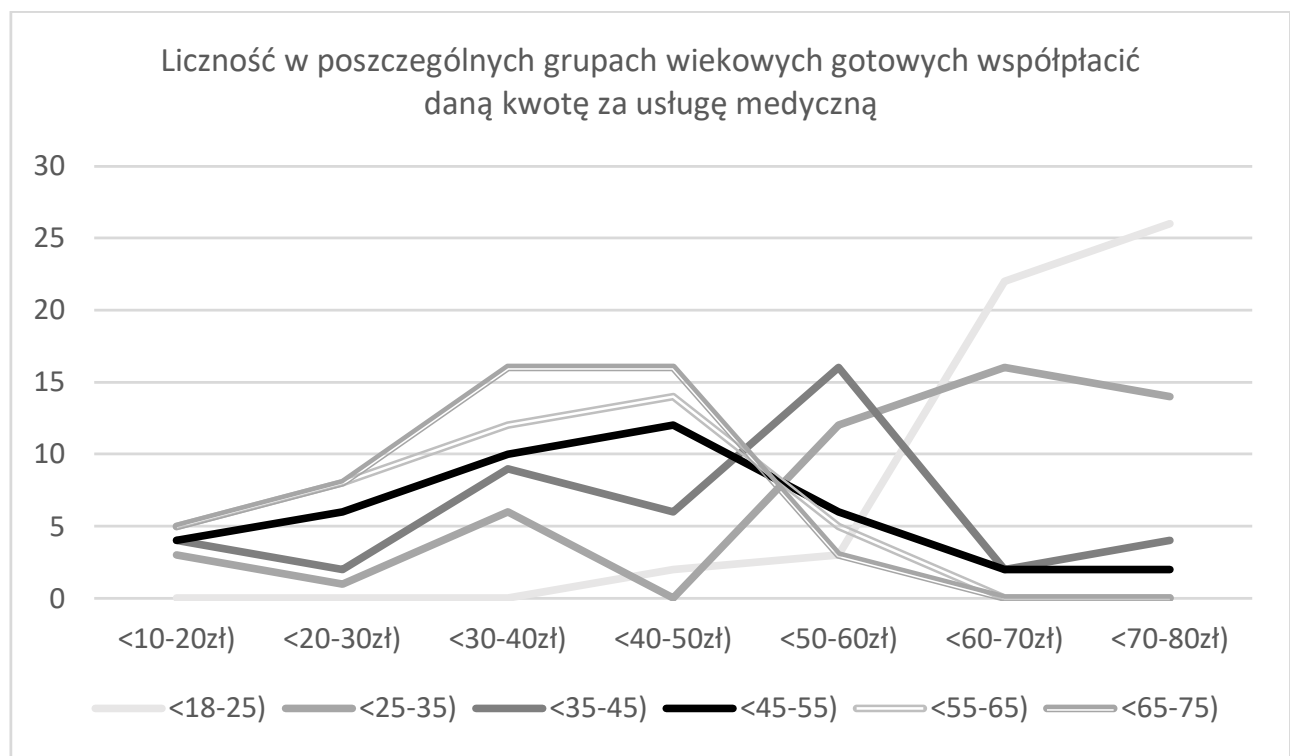

Rysunek 2. Korelacja pomiędzy wysokością kwoty wspólpłacenia a ilością osób gotowych zapłacić daną kwotę za usługę medyczną w nowym proponowanym procesie diagnostyczno-leczniczym

Źródło: Opracowanie własne

Na Rysunku 3, Rysunku 4 oraz Rysunku 5 przedstawiono innowacyjny model lecznictwa bez podziału na lecznictwo ambulatoryjne i lecznictwo w trybie stacjonarnym. Przedstawiony model wymaga infrastruktury równorzędnej niewielkiej jednostki medycznej lecznictwa stacjonarnego z SOR-em, która wymagać będzie pewnego rodzaju przekształceń, tak aby część infrastruktury służąca diagnostyce była skoncentrowana na wejściu do systemu. Przedstawiony innowacyjny model procesu diagnostyczno-leczniczego wymaga pewnego rodzaju założeń początkowych:

- System dysponuje oprogramowaniem, którego produktem finalnym w rękach pacjentów jest karta czipowa, na której znajdują się wszystkie dane dotyczące chorób przebytych, wdrożonego leczenia, zaordynowanych leków, zawierające rejestr wykupień leków, rejestr lekarzy uczestniczących w kolejnych procesach diagnostyczno-leczniczych.

- System czytników wspomnianych powyżej kart czipowych pacjentów na każdym etapie działań diagnostyczno-leczniczych, łącznie z ambulatorium oraz wszystkimi miejscami badań diagnostycznych, przez które przechodzi potencjalny pacjent.

- Dopracowana w szczegółach ankieta wejściowa, która wypełniona przez pacjenta pozwoli na wstępne zweryfikowanie ścieżki diagnostyczno-leczniczej celowanej w potrzeby danego pacjenta. 
- Wieloosobowe sale, do których trafia pacjent natychmiast po wejściu do systemu. Sale te wyposażone są $\mathrm{w}$ wielopoziomowe siedziska z przepierzeniem pomiędzy poszczególnymi siedziskami. Sale nie posiadają żadnych stanowisk pielęgniarsko-lekarskich, są jedynie monitorowane dla bezpieczeństwa potencjalnych pacjentów. W salach panuje spokój, jest możliwość oglądania telewizji lub muzyki w systemie słuchawkowym. Do sal pacjenci powracają po każdym etapie diagnostyki. W trakcie pobytu można zamówić posiłek lub korzystać z własnego prowiantu. Posiłki zamawiane przez pacjenta są płatne. Indywidualne miejsce pacjenta jest tak wyposażone, aby pacjent mógł spożyć posiłek w sposób komfortowy.

- Na wejściu do systemu istnieje minimum $n=5 / 10$ stanowisk lekarza pierwszego kontaktu.

- Wyżej wymieniona liczba stanowisk lekarza pierwszego kontaktu wymaga około $75 \%$ tej liczby trzy-/czteroosobowych zespołów specjalistów pierwszego etapu oraz jedno-/dwuosobowych zespołów specjalistów drugiego etapu.

- Na wejściu do systemu istnieje minimum $n=10$ stanowisk ambulatoryjnych.

- Na wejściu do systemu istnieje minimum $n=5$ stanowisk USG, UKG, innych.

- Na wejściu do systemu istnieją diagnostyczne stanowiska TK, MR, PET, inne rozliczane (również) w systemie usług outsourcingowych.

- Każdy etap procesu diagnostyczno-leczniczego podlega współpłaceniu ze strony pacjenta w sposób: bezpośredniej opłaty lub stworzenia dodatkowego ubezpieczenia skorelowanego $\mathrm{z}$ daną jednostką medyczną.

- Sposób zatrudnienia poszczególnych pracowników wymaga oddzielnego opracowania opartego na szczegółowych rozmowach ze środowiskiem medycznym iokołomedycznym.

Na Rysunkach 3-5 przedstawiono proces diagnostyczno-leczniczy skierowany do lokalnej społeczności.

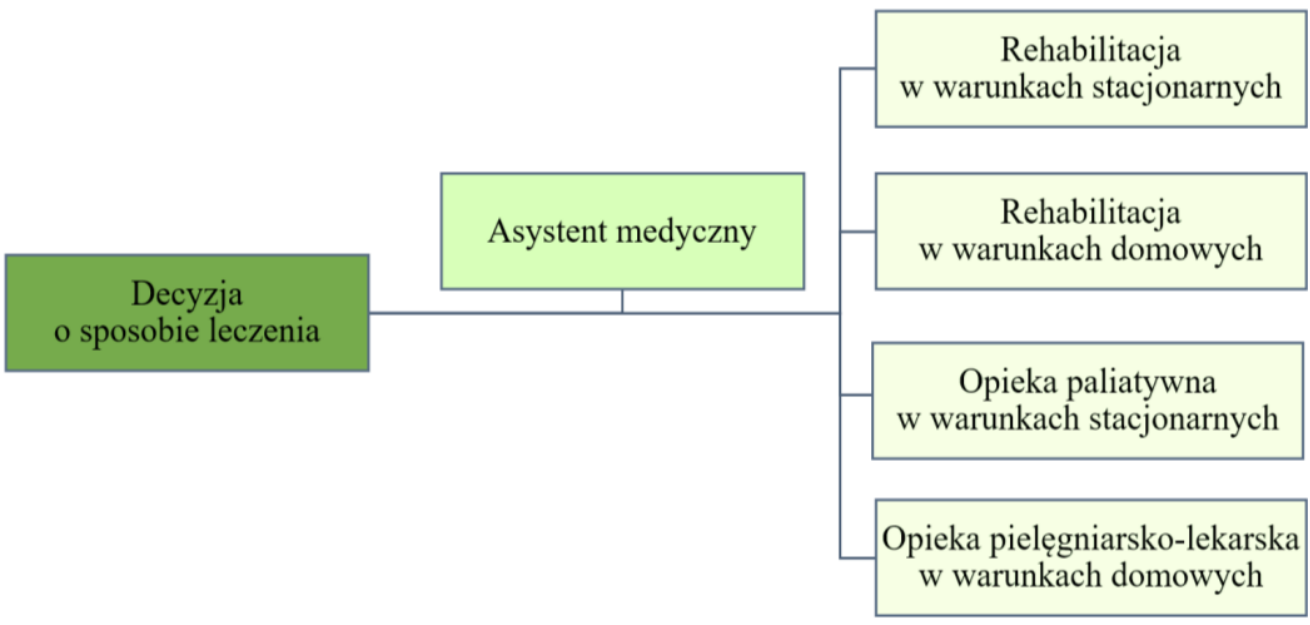

Rysunek 3. Innowacyjny model procesu diagnostyczno-leczniczego nr 1

Źródło: Opracowanie własne 


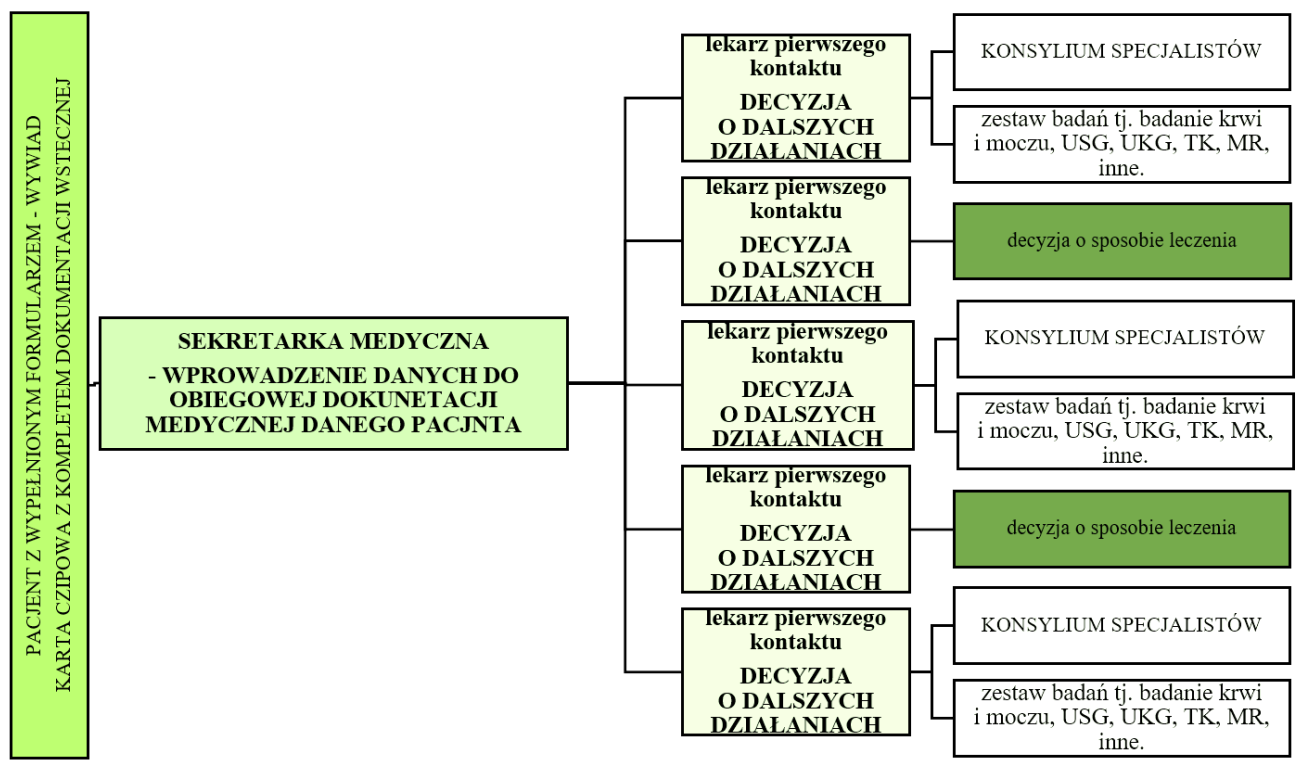

Rysunek 4. Innowacyjny model procesu diagnostyczno-leczniczego $\mathrm{nr} 2$

Źródło: Opracowanie własne
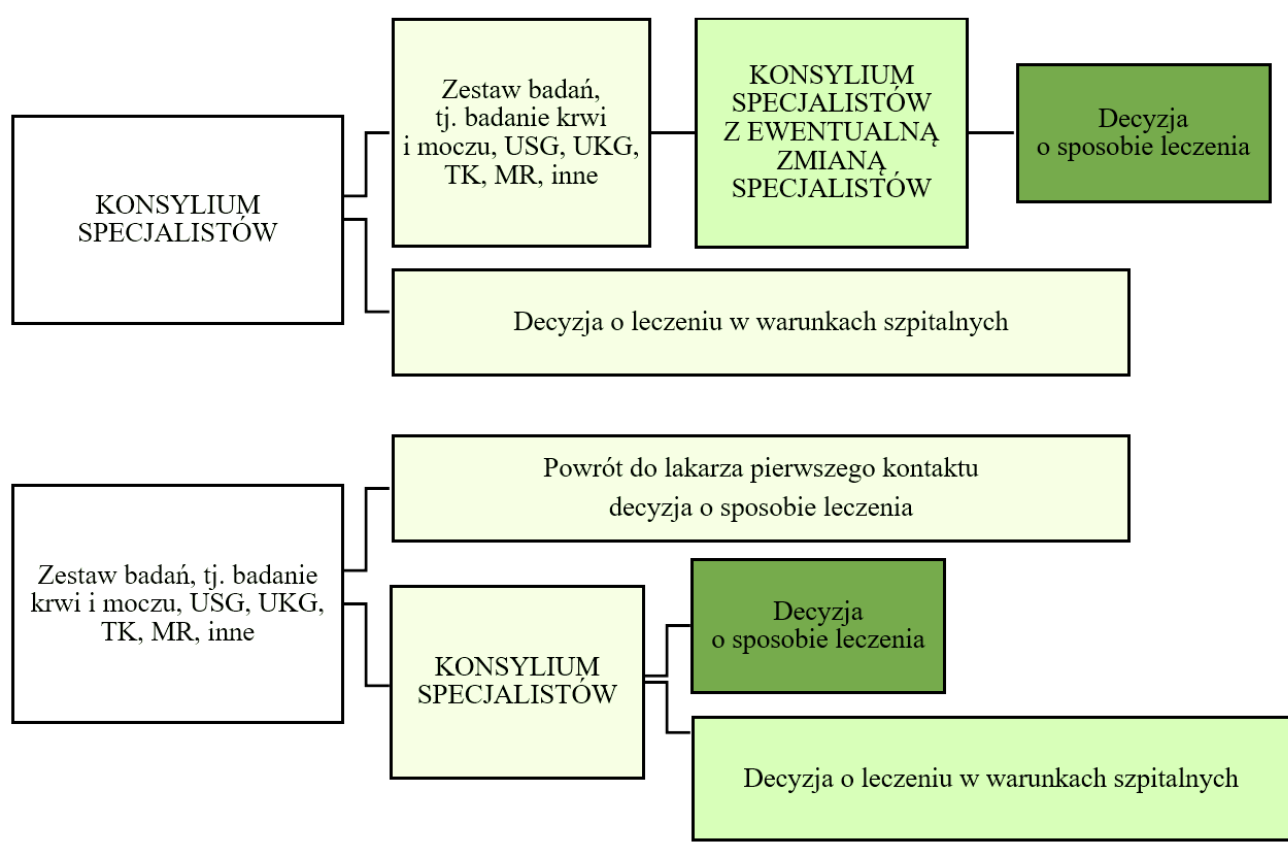

Rysunek 5. Innowacyjny model procesu diagnostyczno-leczniczego nr 3

Źródło: Opracowanie własne 
Na Rysunku 6 zaprezentowano sekwencję czasową 8 godzin pracy całego zespołu specjalistów. Założono, że zespoły pracują w systemie 8-godzinnym. Uwzględniono 15-minutowy zapas czasowy, przypadający na każdą godzinę pracy całego zespołu.

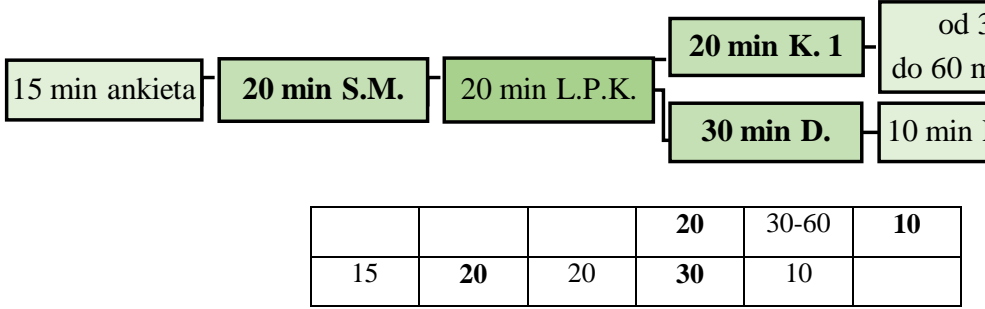

Gdzie: 15 min - pacjent wypisuje ankiete; 20 min - wprowadzenie danych z ankiety (sekretarka medyczna) - *; 20 min lekarz pierwszego kontaktu - **; 20 min konsylium 1 (3-/4-osobowe) - ***; 30 min diagnostyka podstawowa $-\wedge$; 10 min lekarz pierwszego kontaktu etap 2 - ^^; 30-60 min diagnostyka szczegółowa $-\wedge \wedge$; 10 min konsylium 2 (2-osobowe) - *^

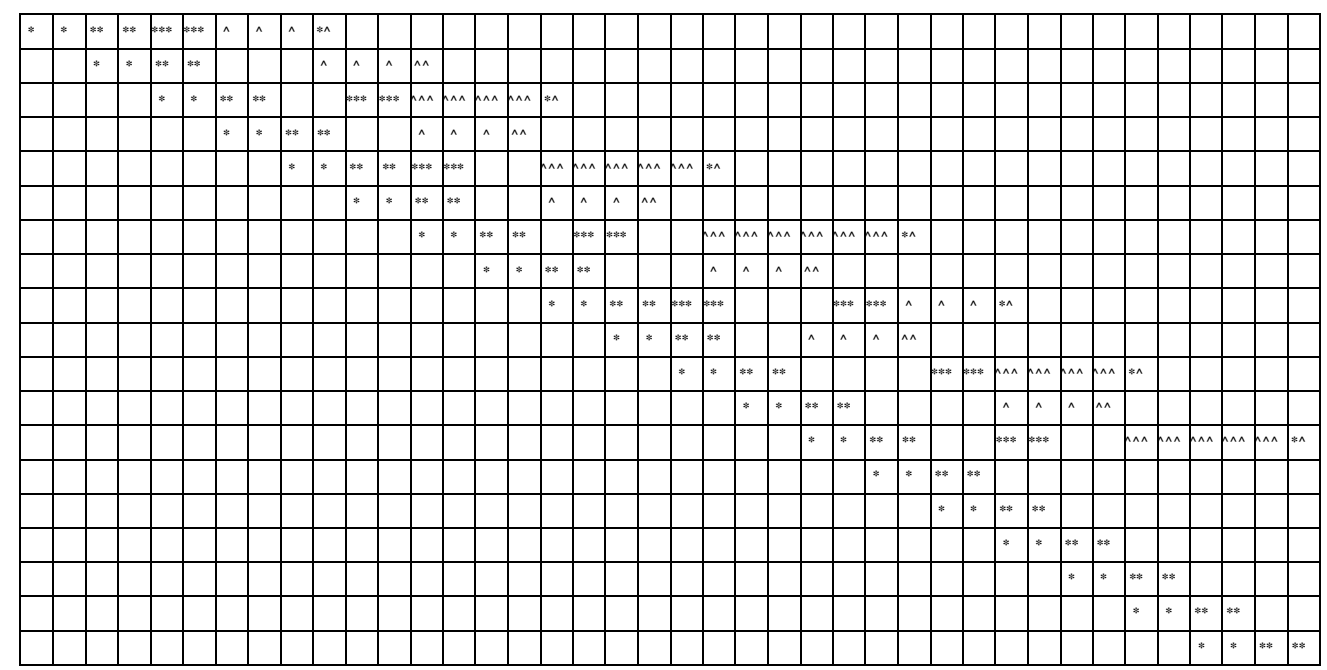

Rysunek 6. Sekwencja czasowa dla jednego zespołu specjalistów dla 7,5 h (w przybliżeniu jednego dyżuru (8h))

Źródło: Opracowanie własne

Sumując założenia przedstawione na Rysunku 6, można wnioskować, że zespół składający się z: sekretarki medycznej, jednego lekarza pierwszego kontaktu, czteroosobowego zespołu lekarzy specjalistów (w różnej konfiguracji, bo zakładamy, że takich kompletnych zespołów w trakcie jednego dyżuru pracuje (w zależności od posiadanej infrastruktury) kilka), lekarza specjalisty USG, lekarza specjalisty UKG, minimalnego niezbędnego zespołu nieodzownego do przeprowadzenia badania TK, minimalnego niezbędnego zespołu nieodzownego do przeprowadzenia badania MR, minimalnego niezbędnego zespołu nieodzownego do przeprowadzenia badania PET, zespołu laboratorium, zespołu radiologów jest w stanie gruntownie przebadać 13 pacjentów. Dodatkowo lekarz pierwszego kontaktu może zbadać 6 pacjentów, którzy nie wymagają innych działań medycznych. 
Zakładając ponadto, że takich zespołów w trakcie trwania jednego dyżuru pracuje pięć, to w trakcie pracy trzyzmianowej system jest w stanie w wciągu jednej doby gruntownie przebadać 195 pacjentów + 90 pacjentów, którzy wymagają jedynie spotkania z lekarzem pierwszego kontaktu. Zatem w tygodniu (pomijając soboty i niedziele) może przebadać $975+450$, a w miesiącu $4485+2070$ pacjentów, więc w roku $53820+24840$ pacjentów, czyli w sumie 78660 pacjentów.

W tym miejscu należy dodać, że system został obliczony w największym możliwym obciążeniu w odniesieniu do czasu przeznaczonego na poszczególne procedury. Każdemu bowiem pacjentowi przypisano pokaźny pakiet badań diagnostycznych oraz spotkanie z lekarzami specjalistami. Na podstawie doświadczeń można przypuszczać, że takiego rozbudowanego procesu diagnostyczno-leczniczego będzie potrzebowało około 50-65\% pacjentów, natomiast pozostała część pacjentów będzie wymagała jedynie wizyty u lekarza pierwszego kontaktu. Kolejnym spodziewanym plusem wyboru tego rodzaju procesu diagnostyczno-leczniczego jest to, że po upływie czasu ta sama grupa pacjentów, która jest tak szczegółowo przebadana, będzie wymagała coraz mniej nakładów czasowych i każdych innych ordynowanych przez tego rodzaju system. Będą bowiem prawidłowo zdiagnozowani, prawidłowo zaopatrzeni w leki, prawidłowo prowadzeni w ujęciu holistycznego spostrzegania chorób wspólistniejących.

W tym miejscu należy zweryfikować częstość korzystania potencjalnego mieszkańca z usług medycznych, w każdej możliwej konfiguracji. Badaniu poddano pacjentów $(\mathrm{n}=90)$. Na podstawie uzyskanych danych ustalono:

$$
\bar{x}=\frac{1}{n} \frac{\sum_{i=1}^{k} x_{i}}{n}=\frac{1400}{90}=15,55
$$

Interpretacja: średnia deklarowanych wizyt pacjentów poddanych badaniu empirycznemu w trakcie roku wynosi przeciętnie 11 razy.

$$
S_{(x)}^{2}=\sqrt{\frac{\sum_{i=i}^{k}\left(x_{i}-\bar{x}\right)^{2}}{n}}=\sqrt{\frac{499,2}{90}}=\sqrt{5,55}=2,36
$$

Interpretacja: uzyskane wyniki deklarowanych wizyt pacjentów w tracie roku odchylają się przeciętnie o około 2 razy. Oznacza to, że w myśl reguły 3Sigma około $68,3 \%$ pacjentów korzysta $\mathrm{z}$ usług medycznych $\pm \sigma=13-17$ razy w ciągu roku.

\section{Podsumowanie}

Zaproponowany powyżej innowacyjny model procesu diagnostyczno-leczniczego zapewnia potencjalnemu pacjentowi kompleksowość usług medycznych (skoncentrowanych zarówno w czasie, jak i w przestrzeni), która zapewni celowość diagnostyki, a ta z kolei celowane leczenie. Obecnie proponowany proces diagnostyczny wydłuża czas uzyskania ostatecznej diagnozy dla danego pacjenta, a lekarze specjaliści (z powodu braku możliwości kontaktu pomiędzy sobą) proponują niejednokrotnie leczenie farmakologiczne znoszące uzyskanie właściwych efektów leczniczych. Ponadto proponowany autorski proces diagnostyczno-leczniczy w sposób znaczący skróci czas oczekiwania potencjalnego pacjenta na wizytę u lekarza specjalisty. 
Można również domniemywać, że konsylium złożone z kilku lekarzy specjalistów celniej dostosuje leczenie do pacjentów z chorobami współistniejącymi, a należy dodać, że tego rodzaju pacjentów jest coraz więcej. Przyjmując, że województwo opolskie zamieszkuje 980771 mieszkańców (stan na 2020 rok), z czego około 75\% to osoby dorosłe, to w taki sposób zorganizowany proces diagnostyczno-leczniczy wymaga około 9 takich ośrodków, które są w stanie obsłużyć całe województwo (dotyczy osób dorosłych) w taki sposób, że każdy mieszkaniec skorzysta minimum 1 raz w roku z tak zorganizowanego procesu diagnostyczno-leczniczego.

\section{Literatura}

1. Bukowska-Piestrzyńska A. (2007), Marketing usług zdrowotnych. Od budowania wizerunku do zadowolenia klienta, CeDeWu, Warszawa.

2. CEESTAHC (2017), Modelowy samorzadowy program polityki zdrowotnej profilaktyki grypy $w$ grupach ryzyka, Central and Eastern European Society of Technology Assessment in Health Care CEESTAHC, Ogólnopolski Program Zwalczania Grypy, Kraków, https://www.ceestahc .org/pliki/nasze_publikacje/programy_zdrowotne/profilaktyka_grypy_2017.pdf (dostęp: 22.11.2020).

3. European Observatory on Health Systems and Policies (2021), www.euro.who.int/en/about-us/ partners/observatory (dostęp: 13.11.2020).

4. Healthcare in Denmark - An Overview, Ministry of Health, København 2017.

5. https://pl.europa.jobs/art-sluzba-zdrowia-w-danii// (dostęp: 08.12.2020).

6. https://www.fhi.no/nyheter/2020/pasientene-er-stort-sett-fornoyd-med-sykehusoppholdet/;2020 (dostęp: 08.12.2020).

7. https://www.politykazdrowotna.com/25267.publiczna-opieka-zdrowotna-i wspolplacenieczyli-dunski-sposób-na-ochrone-zdrowia (dostęp: 13.11.2020).

8. https://www.zus.pl/documents/10182/251386/Dania/dde50c95-da6e-40ce-a07cdc926b5e168f (dostęp: 13.11.2020).

9. Jasiński M., Kowalski M. (2007), Fałszywa sprzeczność: metodologia jakościowa czy ilościowa?, [w:] Haber A. (red.), Ewaluacja ,ex-post”. Teoria i praktyka badawcza, Polska Agencja Rozwoju Przedsiębiorczości, Warszawa.

10. Jopkiewicz S. (2019), Jakość w sektorze zdrowia w świetle badań ustug zdrowotnych, [w:] Krawczyk-Sokołowska I. (red.), Zrównoważony rozwój w zarządzaniu i finansach, Wydawnictwo Politechniki Częstochowskiej, Częstochowa.

11. Korporowicz L. (1997), Słownik ważniejszych pojęć, [w:] Ewolucja w edukacji, Oficyna Naukowa, Warszawa.

12. Łyp K. (2019), Model medicbiznesu dla procesu diagnostyczno-leczniczego w Polsce, [w: Stachera-Włodarczyk S., Cichoń S. (red.), Zrównoważony rozwój w zarządzaniu, Wydawnictwo Wydziału Zarządzania Politechniki Częstochowskiej, Częstochowa.

13. Schmidt M., Schmidt S.A.J., Adelborg K., Sundbøll J., Laugesen K., Ehrenstein V., Sørensen H.T. (2019), The Danish Health Care System and Epidemiological Research: from Health Care Contacts to Database Records, „Clinical Epidemiology”, Vol. 11.

14. Szymaszek Ł. (2018), Branża ochrony zdrowia w Danii, Biuro Handlowe w Kopenhadze Polska Agencja Inwestycji i Handlu.

15. Tikkanen R., Osborn R., Mossialos E., Djordjevic A., Wharton G.A. (2020), International Health Care System Profiles. Denmark, The Common Wealth Fund, June 5, https:// www.commonwealthfund.org/international-health-policy-center/countries/denmark (dostep: 15.12.2020).

16. Wismar M., Busse R., Schwartz F.W. (1999), Health Targets, Care and Policy in the EU: Setting the Agenda, „Eurohealth”, Vol. 15, No. 3. 
INNOVATIVE MODEL OF DIAGNOSTIC AND TREATMENT PROCESS

Abstract: Internal solutions in medical units, shaping the order of activities included in the diagnostic and therapeutic process intended for a Polish patient, threaten the safe and effective achievement of therapeutic benefits, creating only the appearance of employees' efforts. The main aim of the article is to present the proprietary, innovative model of the diagnostic and therapeutic process, which allowed effective satisfaction of the social demand for health services in Poland. The subjects of the empirical studies were patients of the departments of the University Teaching Hospital in Opole. The subject of the research was the willingness of patients to co-pay for individual stages of the diagnostic and therapeutic process and the declared amount of co-payment. A questionnaire study, supplemented with an interview, was conducted.

Keywords: health protection, implementation of diagnostic and therapeutic process, management in health care 